\title{
Ground Zero Revisited - Museums and Materiality in an Age of Global Pandemic
}

\author{
Lindsay Anne Balfour
}

In March 2020, New York City became ground zero yet again, and what was the epicentre of terrorist attack in 2001 has arisen twenty years later as a nucleus of global pandemic. Once again, the New York Historical Society is collecting artefacts, compiling archives of digital detritus - the everyday messages of hope and despair not so much emerging in the era of COVID-19, as returning as what I shall describe as autoimmune remnants of a trauma the city will never fully cauterize from open wound to closed scar. New York was not prepared for the virus but its cultural institutions are oddly prepared to take life and memorialization off site and online so long as the limits of the digital are recognized; it is never enough. New York taught us all how to mourn in the twenty-first century, and the museum once again serves to unify a community which may have forgotten what it meant to live alongside others in those early days of suspicion, intensified security apparatus, and mass graves - uncannily familiar once more.

Taking museums online has been touted as a necessary and democratic shift in twenty-first century museology, yet these moves have become especially complicated in places where tangible remains serve as the most poignant artefacts of memorialization. Most concerns over the digitalization of the 9/11 story, for example, centre on fears that the material significance of the site will be lost - a fair claim - or that new technological applications designed to augment the visitor experience will turn a participatory encounter into a private one. Aaron Hess and Art Herbig claim that 'convergent technologies challenge the memorializing process, providing information in place of imagination' (Hess and Herbig 2013: 2207). We could add to these critiques issues raised around the gamification of digital memorialization, the lack of historicization within mobile media, concerns over entertainment and commercial repurposing, and user narcissism. Even the most sombre memorial museums are plagued by the questionable use of digital devices by visitors, from handheld 'selfie sticks' to smiling Instagram photos in front of mass graves, or Pokémon Go, which at one point had users chasing virtual creatures across the plaza at Ground Zero and capturing them, in some unfortunate cases in the memorial pools.

To be sure, the highlighted aspects of the 9/11 Museum and Memorial are the towers' very tangible remains. Even in the first few days of the recovery effort, workers scrawled the word SAVE in spray paint on remnants of the buildings they thought should be preserved. So much about the $9 / 11$ narrative is about scale and site specificity: the dimensions of the towers, the largest surviving artefacts (including massive pieces of steel, fire engines and an entire staircase), the force of the collapse, the expanse of the slurry wall, the depth of the seven storey footprint, and more. The museum itself is an enormous space built around some of the largest objects from that day. But do we lose this scale when memorialization becomes confined to what is, in many cases, a handheld screen? These are questions scholars of memorial museums were already investigating when the COVID-19 pandemic forced almost all museums in New York City, the 9/11 Museum included, to close 'temporarily' in early March 2020.

The answers come quickly and as no surprise. While memorial culture can certainly shift online - and has done so for years - there is a sheer enormity and gravity that cannot be substituted with digital affect. Yet while the 9/11 Memorial and Museum relies heavily on the emotive weight of its tangible and situated footprint, it has always incorporated the digital. Augmented reality via an early app, Explore 9/11, long before the site opened to the public; the painstaking documentation of artefacts via online archives; and the ethereal Tribute 
in Light are examples of how the 9/11 story was a digital memorial first, preceding its built structure by several years. But transferring affect out of brick and mortar when it is literally the brick and mortar that the site commemorates is complicated: in situ ruin and haunted traces do not translate well beyond material gravitas. Beyond $9 / 11$, what does this mean for the potential of convergence technologies in the process of memorializing the epidemic itself? These questions are not new in the context of COVID-19 but are perhaps more urgent than ever, as we grapple with the turn to technology as a surrogate for what we cannot physically provide. The digital endures but it also contains. It limits. And rather than try to account for this lacuna, the museum does well to embrace it. Take composer William Basinski's video and sound piece The Disintegration Loops, ${ }^{1}$ for instance, one of many digital installations incorporated into the memorial story and museum exhibition which offers poignant insights into pandemic as well.

In the summer of 2001 , while attempting to convert his old, analogue tapes into a digital format, Basinski discovered that his compositions were turning to dust in the machine. Rather than lament the destruction, however, he chose to let them disintegrate further, the result being an extended series of loops whose sonic structure breaks down successively with each cycle. The Disintegration Loops sounds initially like a short track of music being played over and over again. A longer listen, however, reveals that the track is one long recording, the sound quality slowly crumbling, leaving extended moments of silence, crackling feedback, and muddy distortion. In a bizarre and ultimately poignant twist of fate, the recording process for this work was completed on the morning of September 11, 2001, and a version of it now resides in the historical exhibition, where it plays repeatedly in tandem with video feed that Basinski captured from a friend's rooftop. The installation uses the digital to return the towers - if not in cityscape, then in soundscape - to an ethereal form, not unlike the phantasmagorical Tribute in Light that illuminates the Manhattan skyline on each anniversary of the 9/11 attacks. In time, the footprints of pandemic may imprint themselves on our artistic landscape as well, new elegies to immunity gone awry.

As a digital elegy to September 11, The Disintegration Loops conjures not only a common post $9 / 11$ cultural anxiety - the notion of a stable self being breached by a foreignness that was always already inside - but also a process of ruination via digitalization that recalls Derridean autoimmunity, described as 'that strange behavior where a living being, in quasisuicidal fashion, "itself" works to destroy its own protection, to immunize itself against its "own" immunity' (Borradori 2003: 94). Indeed, while Basinski's installation complements the commemorative and affective terrain of the museum's memorial narrative, The Loops also reminds us of the limits of materiality; each subsequent loop is not a copy but an assemblage of remains from the previous cycle: a work only possible by removing its own protection against destruction. This, of course, is the value of the piece, as a representation of the impossible desire to return to the sense of before that predated both terror attack and COVID-19. Its purpose is not to fill in the gaps left by the towers and assuage the feelings of loss but, rather, to highlight that those losses as irrecoverable, aside from a trace that diminishes ad infinitum. The Disintegration Loops thus preserves not the original, and not a copy, but voided remnants and, in doing so, reminds us that traumatic memory is punctuated by gaps and absences; it insists on the recognition of other, stranger, incomplete and imperfect ways of knowing and remembering, a lesson museums might do well to remember now in the rush to migrate online.

This point was underscored when, on 13 March 2020, the 9/11 Memorial and Museum closed its doors to the public and directed visitors to its online and digital programming. Invitations to learn about the story of $9 / 11$ via online catalogues, video recordings of past public programs, and interviews with family members, survivors, and first responders were reinforced but - importantly - not created anew. These options were already available and reflect the museum's commitment to diverse (and even divergent) ways of learning and remembering. At the same time, they are incomplete. There is perhaps no better illustration of this than the medical examiner's repository, located seven storeys beneath the memorial plaza at the museum's bedrock level, where the unidentified and unclaimed remains of 9/11 victims lie, temporarily or in perpetuity, virtually indistinguishable from the dust in Basinski's recorder or that which drifts in the air around the site. Indeed, those who had nothing to bury 
after $9 / 11$ know all too well the grief facing those who mourn loved ones lost to pandemic, where a victim is identifiable, but often unreachable. They also know the exact moment where the virtual becomes never enough. A digital image or voicemail recording saved from two decades ago does not account for the lack of a body, just as a Zoom video chat could never replace a final goodbye to those incubated in an ICU. Perhaps COVID-19 serves museums everywhere as a reminder that the digital does not augment permanence or guarantee immunity from forgetting, but rather reminds us that the material was never the thing that sustained us. We sustain one another and have done so all along.

Received: 22 June 2020 Finally accepted: 10 July 2020

\section{Notes}

1 Seeaudio and video recording taken from https://www.youtube.com/watch?v=mjnAE5go9dl, posted by Trevor Music Annex on September 11, 2014. This file is for reference only and cannot provide the full context of this essay. Sharing the actual museum installation is not permitted as video and photography are prohibited within the historical exhibition.

\section{References}

Borradori, G. (2003) Philosophy in a Time of Terror: Dialogues with Jurgen Habermas and Jacques Derrida, Chicago: University of Chicago Press.

Hess, A. and Herbig, A. (2013) 'Recalling the Ghosts of 9/11: Convergent Memorializing at the Opening of the National 9/11 Memorial,' Journal of International Communication, $72207-30$.

\section{Author \\ Dr. Lindsay Anne Balfour \\ Coventry University \\ UK}

Dr. Lindsay Balfour is Assistant Professor of Digital Media in the Centre for Postdigital Cultures at Coventry University. Her research explores the social implications of artificial intelligence and machine learning in relation to memory and popular culture, wearable tech, and the anthropocentrism of sentient code. Dr. Balfour completed her PhD at the University of British Columbia with the support of the Social Sciences and Humanities Research Council of Canada, and was an Andrew W. Mellon Postdoctoral Fellow at the September 11 Memorial and Museum and New York University. She is the author of Hospitality in a Time of Terror: Strangers at the Gate (2017). 